AGRITECH, Vol. 37, No. 1, Februari 2017, Hal. 81-87 DOI: http://dx.doi.org/10.22146/agritech.17013 ISSN 0216-0455 (Print), ISSN 2527-3825 (Online) Tersedia online di https://jurnal.ugm.ac.id/agritech/

\title{
Profil Antioksidan Darah Tikus Diabetes dengan Asupan Beras Merah yang Diperkaya Kappa-Karagenan dan Ekstrak Antosianin
}

\author{
Blood Antioxidant Profile of Diabetes Rats Feed with Red Rice Enriched with Kappa-Carrageenan \\ and Anthocyanin Extracts
}

\author{
N. Nurhidajah ${ }^{1}$, Mary Astuti' ${ }^{2}$ S. Sardjono ${ }^{2}$, Agnes Murdiati $^{2}$ \\ 'Program Studi Teknologi Pangan, Fakultas Ilmu Keperawatan dan Kesehatan, Universitas Muhammadiyah Semarang, \\ Jl. Kedungmundu Raya No 18 Semarang 50273, Indonesia \\ ${ }^{2}$ Departemen Teknologi Pangan dan Hasil Pertanian, Fakultas Teknologi Pertanian, Universitas Gadjah Mada, \\ Jl. Flora No. 1, Bulaksumur, Yogyakarta 5528, Indonesia \\ Email: nurhidajah@unimus.ac.id
}

Submisi: 17 Desember 2015; Penerimaan: 29 April 2016

\begin{abstract}
ABSTRAK
Penelitian ini bertujuan mengkaji pengaruh pemberian beras merah yang diperkaya kappa-karagenan dan ekstrak antosianin terhadap profil antioksidan darah pada tikus Diabetes Melitus (DM). Indikator penelitian adalah penurunan glukosa darah dan angka Malondialdehid (MDA) serta peningkatan antioksidan plasma dengan metode Ferric Reducing Ability of Plasma (FRAP). Penelitian ini dilakukan secara in vivo pada hewan coba tikus Wistar usia 2,5 bulan dengan desain penelitian rancangan acak lengkap (RAL). Tikus dibagi 6 kelompok pakan, yaitu standar negatif dan positif (normal dan DM), beras merah (BM), beras merah ditambah kappa-karagenan (BMK), beras merah ditambah ekstrak antosianin (BMA), dan beras merah ditambah kappa-karagenan dan ekstrak antosianin (BMKA). Percobaan dilakukan selama 6 minggu. Hasil penelitian menunjukkan bahwa kelompok BMKA setelah intervensi terjadi penurunan kadar glukosa darah dari 234,26 menjadi 84,78 $\mathrm{mg} / \mathrm{dL}(p=0,000)$, MDA kelompok DM dibandingkan BMKA masingmasing 2,175 dan 0,530 $\mu \mathrm{mol} / \mathrm{L}(p=0,000)$ serta FRAP pada kelompok DM dan BMKA masing-masing 69 dan 216 $\mathrm{nmol} / \mathrm{mL}(p=0,000)$. Kesimpulannya adalah beras merah dengan pengkayaan kappa-karagenan dan ekstrak antosianin mampu menurunkan kadar glukosa darah dan meningkatkan antioksidan plasma tikus diabetes yang ditandai dengan penurunan nilai MDA dan peningkatan nilai FRAP.
\end{abstract}

Kata kunci: Antosianin; antioksidan; kappa-karagenan; beras merah

\begin{abstract}
This study aimed to analyze the effect of red rice enriched-kappa-carrageenan and anthocyanin extracts on blood antioxidant profile in diabetic rats. Variables analyzed in this research were blood glucose, malondialdehyde (MDA) level, and plasma antioxidant by Ferric Reducing Ability of Plasma (FRAP) method. This study was conducted in vivo on male Wistar rats aged 2.5 months using completely randomized design. Rats divided into 6 groups based on types of feed, standard feed (normal and DM), red rice (BM), red rice enriched kappa-carrageenan (BMK), red rice enriched extracts of anthocyanin (BMA) and red rice enriched with kappa-carrageenan and extract anthocyanin (BMKA). Experiments were carried out for 6 weeks. Rats feed with red rice showed decreased in blood glucose levels from 234.26 to $84.78 \mathrm{mg} / \mathrm{dL}(p=0.000)$, MDA diabetic group compared to BMKA 2.175 and $0.530 \mu \mathrm{mol} / \mathrm{L}(p=0.000)$ respectively, and the rate of FRAP in DM and BMKA 69 and $216 \mathrm{nmol} / \mathrm{mL}(p=0.000)$ respectively. This study showed that red rice enriched with kappa-carrageenan and anthocyanin extract was able to decrease blood glucose levels and increase plasma antioxidant of diabetic rats which characterized by decreased MDA value and increased FRAP value.
\end{abstract}

Keywords: Anthocyanins; antioxidant; kappa-carrageenan; red rice 


\section{PENDAHULUAN}

Diabetes melitus (DM) merupakan suatu penyakit dengan gangguan metabolisme kronis yang ditandai tingginya kadar glukosa darah sebagai akibat ketidakcukupan fungsi insulin. Insufisiensi fungsi insulin disebabkan oleh defisiensi produksi insulin oleh sel-sel beta langerhans kelenjar pankreas, atau kurang responsifnya sel-sel tubuh terhadap insulin (WHO, 1999). Diabetes melitus tipe 2 dengan jumlah penderita 90-95\%, disebabkan karena multi faktor. Faktor terbesar karena genetik dan pengaruh lingkungan, di antaranya obesitas, diet tinggi lemak, dan rendah serat, serta kurangnya aktifitas tubuh (Depkes, 2005). Menurut International Diabetes Federation (2005), Indonesia diperkirakan mengalami kenaikan prevalensi dari peringkat kelima pada tahun 2003 menjadi peringkat ketiga di dunia pada tahun 2025 .

Beberapa upaya yang dapat dilakukan untuk menangani diabetes yaitu pengobatan, peningkatan aktivitas fisik, dan pengelolaan diet (konsumsi makanan). Antioksidan dari bahan makanan juga terbukti dapat memperbaiki glukosa darah tikus diabetes (Jung dkk., 2007; Gandhi dkk., 2011; Herawati dkk., 2013; Pramitasari, 2014).

Diet beras merah terbukti memiliki potensi untuk pengobatan obesitas dan diabetes tipe 2 pada manusia (Kozuka dkk., 2013). Beberapa hasil penelitian tentang beras merah dan antosianin menunjukkan kemampuannya dalam perbaikan kondisi glikemik. Komponen utama beras merah yaitu oryzanol mampu meningkatkan intoleransi glukosa, mencegah obesitas, dan DM tipe 2. Antosianin pada beras berpigmen menunjukkan aktivitas penghambatan yang signifikan terhadap aldosa reduktase dan memberi kontribusi yang signifikan dalam memerangi komplikasi diabetes (Yawadio dkk., 2007; Zhang dkk., 2010). Yao dkk. (2010) juga membuktikan ada hubungan antara total fenolik beras berpigmen dengan aktivitas penghambatan $\alpha$-glukosidase yang berdampak pada penundaan pencernaan karbohidrat di dalam saluran cerna.

Hasil penelitian Kristanti (2015) menunjukkan beras merah precooked mempunyai kadar serat pangan lebih tinggi dibandingkan beras putih dengan angka masing-masing 7,96 dan 6,83 \% db. Santoso (2011) dan Astawan dkk. (2005) menyampaikan beberapa manfaat serat pangan (dietary fiber) untuk kesehatan yaitu dapat mengontrol berat badan, mencegah gastrointestinal, kanker kolon, mengurangi kadar kolesterol, dan mengontrol glukosa darah pada penderita penyakit diabetes. Diet cukup serat juga menyebabkan terjadinya kompleks karbohidrat dan serat, sehingga daya cerna karbohidrat berkurang. Keadaan tersebut mampu meredam kenaikan glukosa darah dan menjadikannya tetap terkontrol. Salah satu sumber serat pangan adalah rumput laut yang mengandung komponen agar, alginat, dan karagenan yang merupakan senyawa hidrokoloid komersial dari rumput laut merah (Rhodopyaceae). Beberapa keuntungan dari asupan serat pangan bagi penderita diabetes meliputi penghambatan laju postprandial glisemia, mengurangi konsentrasi glukosa basal, dan menaikkan sensitivitas pada insulin (Marsono, 2004). Hasil penelitian ini dapat diaplikasikan sebagai terapi diet pada penyandang diabetes untuk mempertahankan level glukosa darah mendekati normal.

\section{METODE PENELITIAN}

\section{Desain, Waktu, dan Tempat}

Penelitian ini dilakukan secara in vivo pada hewan coba tikus Wistar jantan dengan desain penelitian Rancangan Acak Lengkap (RAL), dari bulan Februari-Desember 2014. Uji in vivo menggunakan hewan coba dilakukan di Laboratorium Pangan dan Gizi, Pusat Studi Pangan dan Gizi UGM Yogyakarta.

\section{Bahan dan Alat}

Bahan yang digunakan dalam penelitian ini meliputi beras merah varietas Mandel Handayani dari Gunung Kidul, kappa-karagenan dari Fakultas MIPAUII, antosianin diekstrak dari beras hitam varietas Melik (Bantul, Yogyakarta).

Bahan pakan standar AIN 93 meliputi maizena, kasein, sukrosa, minyak kedelai, agar-agar (serat), mineral mix, vitamin mix, L-cystin dan cholin bitartrat, Reagen GOD-PAP (Glucose Oksidase-Phenol Amino peroxidase), Streptozotocin (STZ) (Nacalai Tesque, USA), Nicotinamide (NA), reagen uji Malondialdehid (MDA) meliputi asam fosfat, TEP standar, TBA dan reagen uji FRAP, larutan standar $\mathrm{FeSO}_{4} \cdot 7 \mathrm{H}_{2} \mathrm{O}$, buffer asetat $\mathrm{pH} 3,6, \mathrm{TPTZ}, \mathrm{FeCl}_{3} \cdot 6 \mathrm{H}_{2} \mathrm{O}$ dan $\mathrm{FeSO}_{4}$.

Alat yang digunakan dalam penelitian ini adalah kandang individual, botol air, neraca analitik, mangkok aluminium, sarung tangan karet, spuit disposable, tabung eppendorf, tabung reaksi, centrifuge, dan spektrofotometer UV-Vis.

\section{Hewan Percobaan}

Hewan coba yang digunakan dalam penelitian ini adalah 30 ekor tikus jantan galur Wistar berat badan antara 175-250 g, dilengkapi keterangan kelaikan etik nomor: 182/KEC-LPPT/ IX/2014 yang dikeluarkan oleh Komisi Etik Laboratorium Penelitian dan Pengujian Terpadu (LPPT) UGM.

\section{Persiapan Hewan Coba (Induksi STZ-Na)}

Tahap persiapan hewan coba meliputi aklimatisasi selama 5 hari kemudian tikus dipuasakan 1 malam, lalu diinjeksi STZ-Na dengan dosis tunggal STZ $65 \mathrm{mg} / \mathrm{kg}$ berat 
badan (dilarutkan dalam $0,1 \mathrm{~mol} / \mathrm{L}$ buffer sitrat $\mathrm{pH} 4,5$ ) dan $\mathrm{NA} 230 \mathrm{mg} / \mathrm{kg}$ berat badan secara intraperitoneal (Szkudelski, 2012). Setelah induksi, hewan coba diaklimatisasi 5 hari. Tikus dinyatakan diabetes, bila kadar glukosa darah $>200$ $\mathrm{mg} / \mathrm{dl}$ (Anwer, 2014).

Pengukuran kadar glukosa darah dilakukan 1 minggu sekali selama intervensi, MDA dilakukan pada minggu ke 3 dan ke 6 (akhir penelitian), sedangkan FRAP dilakukan diakhir penelitian (pada minggu ke 6).

\section{Pengelompokan Hewan Percobaan dan Intervensi}

Tikus dibagi menjadi 6 kelompok, tiap kelompok terdiri dari 5 ekor tikus.

1. Normal: tikus sehat (tanpa induksi STZ-NA) sebagai kontrol diberi diet pakan standar AIN 93M.

2. DM: tikus diinduksi STZ-NA(DM) diberi pakan standar AIN 93M.

3. BM: tikus DM diberi diet tepung beras merah.

4. BMK: tikus DM diberi diet tepung beras merah + kappa-karagenan.

5. BMA: tikus DM diberi diet tepung beras merah + ekstrak antosianin

6. BMKA: tikus DM diberi diet tepung beras merah + kappa-karagenan + ekstrak antosianin. Intervensi dilakukan selama 6 minggu.

Tabel 1. Komposisi pakan ransum standar (AIN 93M)

\begin{tabular}{ccccccc}
\hline \multirow{2}{*}{ Bahan (g) } & \multicolumn{7}{c}{ Kelompok pakan } \\
\cline { 2 - 7 } & Normal & DM & BM & BMK & BMA & BMKA \\
\hline Maizena & 62,5 & 62,5 & 20 & 19,2 & 20 & 19,2 \\
TBM & 0 & 0 & 62,7 & 0 & 0 & 0 \\
TBMK & 0 & 0 & 0 & 63,9 & 0 & 0 \\
TBMA & 0 & 0 & 0 & 0 & 62,7 & 0 \\
TBMKA & 0 & 0 & 0 & 0 & 0 & 63,9 \\
Kasein & 14 & 14 & 7,91 & 7,79 & 7,91 & 7,83 \\
Sukrosa & 10 & 10 & 15 & 15 & 15 & 15 \\
Minyak kedelai & 4 & 4 & 2,72 & 2,70 & 2,72 & 2,64 \\
Agar-agar (serat) & 5 & 5 & 0 & 0 & 0 & 0 \\
Mineral mix & 3,5 & 3,5 & 3,5 & 3,5 & 3,5 & 3,5 \\
Vitamin mix & 1 & 1 & 1 & 1 & 1 & 1 \\
L-Cystin & 0,18 & 0,18 & 0,18 & 0,18 & 0,18 & 0,18 \\
Cholin Bitartrat & 0,25 & 0,25 & 0,25 & 0,25 & 0,25 & 0,25 \\
\hline Total (g) & 100,4 & 100,4 & 99,73 & 100,0 & 99,73 & 100,02 \\
\hline Kkal & 361,9 & 361,9 & 361,4 & 361,8 & 361,4 & 361,8 \\
\hline Sinyyyyyy & & & & & & 0 \\
\hline
\end{tabular}

Sumber: Reeves dkk. (1993) dengan modifikasi

Keterangan: TBM (tepung beras merah), TBMK (tepung beras merah + kappa-karagenan), TBMA (tepung beras merah + ekstrak antosianin) dan TBMKA (tepung beras merah + kappakaragenan + ekstrak antosianin)
Komposisi masing-masing kelompok pakan dihitung berdasarkan kesamaan kadar protein dan kalori dipaparkan pada Tabel 1 .

Penambahan kappa-karagenan dan ekstrak antosianin berdasarkan nilai tertinggi dari uji sensoris. Kappa-karagenan ditambahkan sebanyak $2 \%$ sedangkan ekstrak antosian 5 mL/100 g beras + kappa-karagenan (Nurhidajah dkk., 2013).

\section{Kadar Glukosa Puasa (GOD-PAP)}

Kadar glukosa puasa ditentukan dengan metode enzimatik Glucose Oxidase-Phenol 4-Aminoantipirin. Penentuan kadar glukosa serum menggunakan kit analisis dari Dia Sys yang terdiri dari larutan standart dan reagen. Sebanyak $10 \mu \mathrm{L}$ serum ditambah reagen GOD-PAP sebanyak $1000 \mu \mathrm{L}$, kemudian divorteks. Larutan diinkubasi pada suhu kamar selama 20 menit pada suhu $20-25^{\circ} \mathrm{C}$, kemudian diukur dengan spektrofotometer pada panjang gelombang $500 \mathrm{~nm}$, kadar glukosa dihitung menggunakan persamaan:

Glukosadarah $\left(\frac{m g}{d l}\right)=\frac{\Delta \text { sampel }}{\Delta \text { standar }} x$ kadar standar

\section{Kadar Malondialdehid (MDA) Plasma (Thiobarbituric Acid)}

Darah tikus diambil minggu ke 3 dan 6 (akhir intervensi) sebanyak $0,1 \mathrm{~mL}$, kemudian dimasukkan ke dalam tabung yang berisi EDTA. Malondialdehid diukur dengan metode TBARS yaitu mengukur konsentrasi Thiobarbituric Acid Reactive Substances. Sebanyak $750 \mu \mathrm{L}$ asam fosfat dimasukkan ke dalam tabung polypropilen $13 \mathrm{~mL}$. Sebanyak $50 \mu \mathrm{L}$ sampel plasma/aquades ditambahkan ke dalam tabung.

Campuran dikocok sampai homogen kemudian ditambahkan $250 \mu \mathrm{L}$ larutan TBA $40 \mathrm{mM}$. Selanjutnya ditambahkan aquades sebanyak $450 \mu \mathrm{L}$ ke dalam tabung dan ditutup rapat. Campuran dididihkan, kemudian didinginkan dalam ice bath. Sampel yang sudah dingin diaplikasikan ke dalam Set Pack C 18-column. Absorbansi diukur dengan spektrofotometer pada panjang gelombang $532 \mathrm{~nm}$.

\section{Analisis Antioksidan Plasma dengan Ferric Reducing Ability of Plasma (FRAP) (Benzie, 1996)}

Pengujian kapasitas antioksidan plasma dengan metode FRAP, sebanyak $30 \mu \mathrm{L}$ reagen FRAP yang telah dihangatkan pada $37{ }^{\circ} \mathrm{C}$ ditambahkan $10 \mu \mathrm{L}$ sampel plasma/larutan standard $\mathrm{FeSO}_{4} \cdot 7 \mathrm{H}_{2} \mathrm{O}$ kemudian ditambah $30 \mu \mathrm{L}$ aquades, dicampur dengan vorteks kemudian diinkubasi selama 5 menit pada suhu $37^{\circ} \mathrm{C}$. Setelah itu dilakukan peneraan absorbansi pada panjang gelombang $593 \mathrm{~nm}$.

Reagen FRAP dibuat dengan mencampurkan $25 \mathrm{~mL}$ buffer asetat $\mathrm{pH}$ 3,6 dengan 2,5 mL larutan TPTZ, dan 2,5 mL larutan $\mathrm{FeCl}_{3} \cdot 6 \mathrm{H}_{2} \mathrm{O}$. Larutan standar $\mathrm{FeSO}_{4}$ dibuat dengan 
rentang kadar 100-1000 $\mu \mathrm{mol} / \mathrm{L}$ untuk pembuatan kurva standar.

\section{HASIL DAN PEMBAHASAN}

Pengaruh Pemberian Pakan Beras Merah dengan Kappakaragenan dan Ekstrak Antosianin terhadap Kadar Glukosa Darah

Kadar glukosa darah hewan coba yang diinduksi STZ mengalami peningkatan di atas $200 \mathrm{mg} / \mathrm{dL}$ pada semua kelompok. Keadaan ini tergolong hiperglikemia yang ditandai dengan kadar glukosa darah di atas normal. Menurut Taguchi (1985), tikus putih galur SD jenis kelamin jantan mempunyai kadar glukosa darah normal 105,2 $\pm 14,2 \mathrm{mg} / \mathrm{dL}$ Pada manusia, glukosa darah sewaktu $>200 \mathrm{mg} / \mathrm{dl}$ atau glukosa darah puasa $>126 \mathrm{mg} / \mathrm{dl}$ dapat digunakan untuk menegakkan diagnosis Diabetes Melitus (Mansjoer dkk., 2007). Data ratarata kadar glukosa dipaparkan pada Gambar 1.

Kadar glukosa darah pada semua kelompok tikus DM yang diberi perlakuan selama 6 minggu mengalami penurunan. Prosentase penurunan kadar glukosa darah tikus DM dengan perlakuan pakan BM, BMK, BMA dan BMKA berturut-turut $57,83 \%, 63,63 \%, 61,11 \%$ dan 63,81\% (dihitung dari kadar glukosa darah setelah induksi). Hal ini disebabkan kandungan serat pangan yang cukup tinggi pada beras merah. Uji Anova menunjukkan ada pengaruh yang sangat signifikan antara perlakuan pakan dengan kadar glukosa darah $(p=0,000)$.

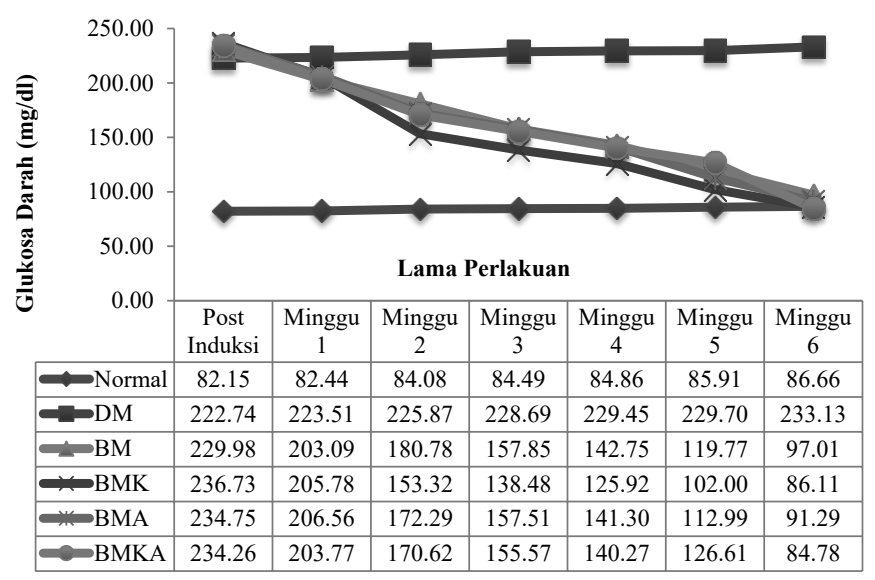

Gambar 1. Rata-rata kadar glukosa darah selama perlakuan (6 minggu)

Keterangan :

Normal : tikus sehat dengan pakan standar AIN 93 M

DM : tikus diabetes dengan pakan standar AIN $93 \mathrm{M}$

BM : tikus diabetes dengan pakan beras merah

BMK : tikus diabetes dengan pakan beras merah + kappa-karagenan

BMA : tikus diabetes, pakan beras merah + antosianin

BMKA : tikus diabetes, pakan beras merah + kappa-karagenan + ekstrak antosianin
Uji lanjut Duncan menunjukkan ada perbedaan kelompok perlakuan kecuali kelompok normal, BMK dan BMKA. Menurut Santoso (2011), serat pangan mampu menyerap air dan mengikat glukosa, sehingga mengurangi ketersediaan glukosa. Diet cukup serat juga menyebabkan terjadinya kompleks karbohidrat dan serat, sehingga daya cerna karbohidrat berkurang. Keadaan tersebut mampu meredam kenaikan glukosa darah dan menjadikannya tetap terkontrol.

Selain serat, antosianin pada beras merah mengindikasikan berfungsi antihiperglikemik. Menurut Banerjee dan Vats (2014), pada kondisi hiperglikemia biasanya diikuti dengan peningkatan produksi radikal bebas atau kegagalan fungsi pertahanan antioksidan dalam tubuh. Hal ini akan menyebabkan terjadinya resistensi insulin. Suda dkk. (2003) berpendapat bahwa tikus hiperglikemik yang diberi antosianin dari ubi jalar varietas Ayamurasaki (100 mg/ $\mathrm{kg}$ ) mampu menurunkan kadar glukosa darah 16,5\% setelah 30 menit dibanding perlakuan kontrol. Hal ini disebabkan terdapatnya efek antihiperglikemik dari antosianin dengan menghambat aktivitas enzim maltase dalam menghasilkan glukosa. Kandungan polifenol pada beras merah juga dapat mempengaruhi penurunan glukosa darah. Konsumsi fenolik terbukti mampu meningkatkan penghambatan enzim $\alpha$-glukosidase yang berperan dalam hidrolisis karbohidrat. Hasil penelitian Yao dkk. (2010) membuktikan bahwa bijibijian berwarna mengandung antosianin berfungsi sebagai antioksidan. Terdapat korelasi positif yang signifikan dari aktivitas antioksidan dan aktivitas penghambatan alphaglukosidase dengan total kandungan antosianin. Beras hitam memiliki aktivitas antioksidan dan alpha-glukosidase inhibitor tertinggi dan ada hubungan antara total fenolik beras dengan aktivitas penghambatan $\alpha$-glukosidase, yang berdampak pada penundaan pencernaan karbohidrat di dalam saluran pencernaan sehingga dapat digunakan sebagai terapi bagi penderita diabetes (Matsui dkk., 2001; 2002).

\section{Pengaruh Pemberian Pakan Beras Merah dengan Kappa- karagenan dan Ekstrak Antosianin terhadap Kadar Malondialdehid (MDA) Plasma Tikus Diabetes}

Malondialdehid (MDA) merupakan produk hasil peroksidasi lipid oleh radikal bebas dalam tubuh dalam bentuk bebas atau terikat dengan jaringan di dalam tubuh yang menjadi salah satu indikator untuk menentukan stres oksidatif dalam tubuh dan merupakan biomarker stres oksidatif (Jeyabalan dan Caritis, 2007; Souza dkk., 2005). Peningkatan stres oksidatif berbanding lurus dengan pembentukan MDA. Proses autooksidasi pada hiperglikemia memicu pembentukan radikal bebas khususnya radikal superoksida $\left(\mathrm{O}_{2}^{-}\right)$dan oksidan hidrogen peroksida $\left(\mathrm{H}_{2} \mathrm{O}_{2}\right)$ melalui reaksi Haber-Weis dan Fenton akan membentuk radikal hidroksil (OH-). Radikal bebas dapat merusak membran sel menjadi 


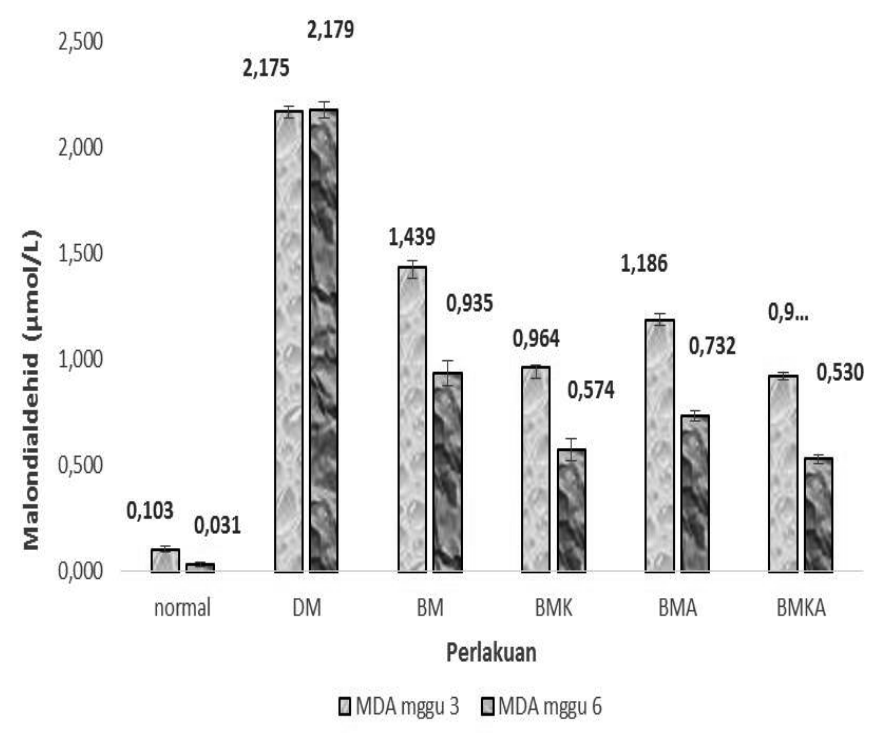

Gambar 2. Perubahan kadar MDA minggu ke 3 dan ke 6

Tabel 2. Uji korelasi antara kadar glukosa darah dan MDA

\begin{tabular}{lcc}
\hline $\begin{array}{l}\text { Parameter (Kadar } \\
\text { glukosa darah) }\end{array}$ & $\begin{array}{c}\text { MDA minggu } \\
\text { ke } 3\end{array}$ & $\begin{array}{c}\text { MDA minggu } \\
\text { ke } 6\end{array}$ \\
\hline $\begin{array}{l}\text { Pearson Correlation } \\
\text { Coefficient }\end{array}$ & 0.779 & 0.927 \\
Sig(2tailed) & & \\
\hline
\end{tabular}

lipid peroksida atau MDA (Baynes, 1991). Rata-rata kadar MDA minggu ke 3 dan 6 dipaparkan seperti Gambar 2.

Gambar 2 menunjukkan kadar MDA pada minggu ke 6 mengalami penurunan pada semua kelompok tikus normal maupun yang diberi perlakuan pakan. Hasil anova menunjukkan ada pengaruh yang sangat signifikan $(p=0,000)$ antara perlakuan pakan terhadap kadar MDA pada minggu ke 3 dan ke 6. Uji lanjut Duncan menunjukkan ada perbedaan antar perlakuan kecuali kelompok BMK dan BMKA. Kappakaragenan yang ditambahkan pada beras merah terbukti memberikan efek terbaik pada penurunan MDA baik pada minggu ke 3 maupun minggu ke 6. Uji korelasi antara glukosa darah dan MDA dipaparkan pada Tabel 2.

Analisis korelasi menunjukkan ada korelasi positif yang sangat bermakna antara kadar glukosa darah dengan MDA baik pada minggu ke 3 maupun akhir intervensi.

\section{Pengaruh Perlakuan Pakan terhadap Kadar Ferric Reducing Ability of Plasma (FRAP)}

Pengujian aktivitas antioksidan dengan metode FRAP (Ferric Reducing Ability of Plasma) didasarkan atas kemampuan senyawa antioksidan dalam mereduksi senyawa besi (III)-tripiridil-triazin menjadi besi (II)-tripiridil triazin pada $\mathrm{pH} 3,6$. Hasil penelitian menunjukkan ada perbedaan

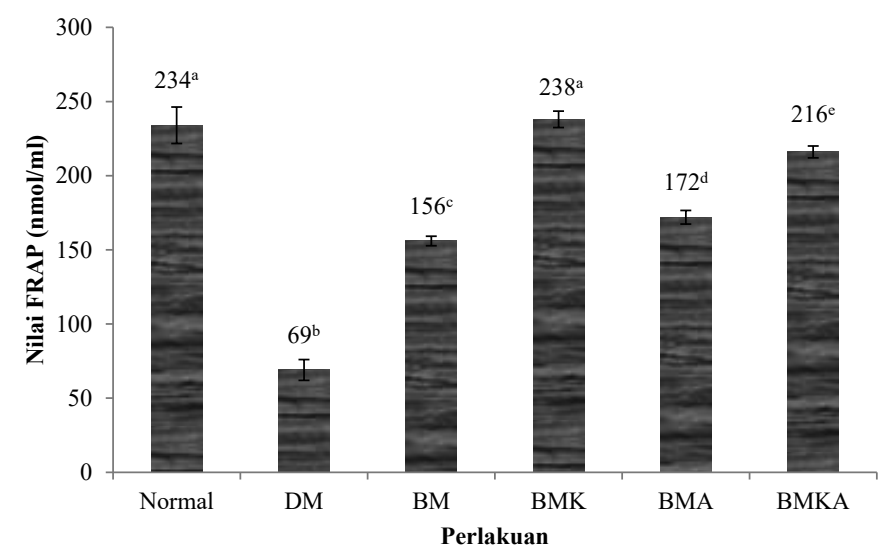

Gambar 3. Pengaruh pemberian pakan terhadap nilai FRAP

yang cukup signifikan nilai FRAP pada kelompok perlakuan BM, BMK, BMA dan BMKA berturut-turut 126,10\%, 244,93 $\%, 149,28 \%$ dan 213,04 \% bila dibandingkan kelompok DM (Gambar 3).

Uji statistik menunjukkan ada pengaruh antara perlakuan pakan dengan nilai FRAP $(p=0,000)$, sedangkan uji lanjut menunjukkan ada perbedaan antar perlakuan kecuali pada kelompok normal dengan kelompok perlakuan beras merah yang ditambah kappa-karagenan. Uji korelasi antara kadar glukosa darah dan FRAP menunjukkan korelasi negatif antara kadar glukosa darah dengan nilai FRAP. Semakin tinggi kadar glukosa darah semakin rendah nilai FRAP. Yao dkk. (2010) membuktikan bahwa antioksidan beras merah memiliki kemampuan menghambat enzim $\alpha$-glukosidase (IC50) sebesar $>1 \mathrm{~g} / \mathrm{mL}$.

Mekanisme penurunan kadar glukosa darah puasa tikus kelompok perlakuan juga dapat terjadi melalui perbaikan status antioksidan darah tikus karena adanya kandungan antioksidan yang tinggi pada pakan sehingga kapasitas antioksidan darah (FRAP) juga tinggi pada tikus kelompok perlakuan.

\section{KESIMPULAN}

Beras merah dan hasil pengkayaannya mampu menurunkan dan mengontrol kadar glukosa darah tikus DM mendekati kondisi normal pada 6 minggu setelah perlakuan dengan variasi penurunan 57,82 \% sampai 63,81\%. Kadar MDA pada minggu ke 3 dan 6 mengalami penurunan pada semua kelompok dengan variasi $33,84 \%$ sapai 57,47 \% (minggu ke 3) dan 57,09 \% sampai 75,69\% (minggu ke 6). Angka FRAP tikus DM menunjukkan peningkatan yang signifikan antara 126,1 \% sampai 244,93\%. Penelitian ini membuktikan bahwa konsumsi beras merah yang diperkaya kappa-karagenan dan ekstrak antosianin mampu memperbaiki kadar glukosa darah dan status antioksidan pada tikus diabetes. 


\section{DAFTAR PUSTAKA}

Anwer, T. (2014). Melatonin ameliorates hyperinsulinemia, glucose intolerance and insulin resistance in STZNicotinamide induced type 2 diabetic rats. International Journal of Pharmacy and Pharmaceutical Sciences 6(2): 133-136.

Astawan, M., Tuti, W. dan Anas, B.H. (2005). Pemanfaatan rumput laut sebagai sumber serat pangan untuk menurunkan kolesterol darah tikus. Hayati 12(1): 2327.

Banerjee, M. dan Vats, P. (2014). Reactive metabolites and antioxidant gene polymorphisms in Type 2 diabetes melitus. Journal Redox Biology 2: 170-177.

Baynes, J.W. (1991). Role of oxidative stress in development of complications in diabetes. Diabetes 40: 405-412.

Benzie, I. dan Strain, J. (1996). The ferric reducing ability of plasma (FRAP) as a measure of "Antioxidant Power": The FRAP assay. Analytical Biochemistry 239: 70-76.

Direktorat Bina Farmasi Komunitas Dan Klinik Direktorat Jenderal Bina Kefarmasian dan Alat Kesehatan departemen Kesehatan RI. (2005). Pharmaceutical care untuk penyakit diabetes melitus.

Gandhi, G.R., Ignacimuthu, S. dan Paulraj, M.G. (2011). Solanum torvum swartzfruit containing phenolic compounds shows antidiabetic and antioxidant effects in streptozotocin induced diabetic rats. Journal Food and Chemical Toxicology 49: 2725-2733.

Herawati, E.R.N., Santosa, U., Astuti, M., Suharwaadji dan Ariani, D. (2013). Pengaruh konsumsi ekstrak antosianin ubi jalar ungu (Ipomoea batatasl.) terhadap glukosa darah, dan produk oksidasi lipid (Malonaldehide) tikus hiperglikemia induksi aloksan. Prosiding Seminar Nasional Konsumsi Pangan Sehat dengan Gizi Seimbang Menuju Tubuh Sehat Bebas Penyakit: 191197. Gadjah Mada University Press, Yogyakarta.

International Diabetes Federation. (2005). Guidelines task force global for type 2 diabetes. Brussels.

Jeyabalan, A. dan Caritis, S.N. (2006). Antioxidantand the prevention of preeklapmsia-unresolved issues. The New England Journal ofMedicine 354(17): 1841-3.

Jung, E.H., Kim, S.R., Hwang, I.K. dan Ha, T.Y. (2007). Hypoglycemic Effects of a Phenolic Acid Fraction of Rice Bran and Ferulic Acid in C57BL/KsJdb/db Mice. Journal of Agricultural and Food Chemistry 55: 98009804.
Kozukaa, C., Yabikua, K., Takayamab, C., Matsushitac, M., Shimabukurod, M., Masuzakia, H. (2013). Natural food science based novel approach toward prevention and treatment of obesity and type 2 diabetes: Recent studies on brown rice and oryzanol. Obesity Research and Clinical Practice 7: 165-172.

Kristanti, D. (2015). Perbandingan efek diet beras merah (mandel handayani) dan Beras putih (ir64) precooked pada kadar glukosa darah, Antioksidan darah, profil mikrobiota, dan short chain Fatty acids (scfa) digesta tikus wistar hiperglikemia. Tesis. Program Studi Pascasarjana Fakultas Teknologi Pertanian UGM, Yogyakarta.

Matsui, T., Ueda, T., Oki, T., Sugita, K., Terahara, N. dan Matsumoto, K. (2001). $\alpha$-glucosidase inhibitory action of natural acylated anthocyanins. 2. $\alpha$-glucosidase inhibition by isolated acylated anthocyanins. Journal of Agricultural and Food Chemistry 49: 1952-1956.

Matsui, T., Ebuchi, S., Kobayashi, M., Fukui, K., Sugita, K., Terahara, N. dan Matsumoto, K. (2002). Antihyperglycemic effect of diacylated anthocyanin derived from ipomoea batatas cultivar ayamurasaki can be achieved through the $\alpha$-glucosidase inhibitory action. Journal of Agricultural and Food Chemistry 50: 7244-7248.

Mansjoer, A., Triyanti, K., Savitri, R., Wardhani, W.I. dan Setiowulan, W. (2007). Kapita Selekta Kedokteran. Edisi 3. Jilid 1: 580-588. Jakarta.

Marsono, Y. (2004). Serat pangan dalam perspektif ilmu gizi. Pidato Pengukuhan Jabatan Guru Besar pada Fakultas Teknologi Pertanian, Universitas Gadjah Mada, Yogyakarta.

Nurhidajah, Astuti. M., Sardjono dan Murdiati, A. (2013). Evaluasi sifat fisik, sensoris dan kimia beras merah yang diperkaya kappa-karagenan dan ekstrak antosianin. Prosiding Seminar Nasional Konsumsi Pangan Sehat dengan Gizi Seimbang Menuju Tubuh Sehat Bebas Penyakit 219-225. Gadjah Mada University Press, Yogyakarta.

Pramitasari, R. (2014). Potensi antioksidatif minuman fungsional berbasis beras hitam (Oryza Sativa L. Indica) dan kedelai hitam (Glycine Max L. Merr.) untuk lansia penyandang diabetes melitus tipe 2. Tesis. Program Studi Pascasarjana Fakultas Teknologi Pertanian UGM, Yogyakarta.

Reeves, P.G., F.H. Nielsen. dan Fahey, G.C. Jr. (1993). AIN93 purified diets for laboratory rodents: Final report of the American Institute of Nutrition and adhoc writing 
committee on the reformulation of the AIN-76A diet. Journal of Nutrition 123:1939-1951.

Santoso A. (2011). Serat pangan (dietary fiber) dan manfaatnya bagi kesehatan. Magistra No. 75 Th. XXIII ISSN 0215-9511.

Souza, T.P., de Oliveira, P.R. dan Pereira, B. (2005). Physical exercise and oxidative stress. Effect of intense physical exercise on the urinary chemiluminescence and plasmatic malondialdehyde. Revista Brasileira de Medicina do Esporte 11: 1.

Suda, I., Oki, T., Masuda, M., Kobayashi, M., Nishiba,Y. dan Furuta, S. (2003). Physiological functionality of purplefleshed sweet potatoes containing anthocyanins and their utilization in foods. Japan Agricultural Research Quarterly 37(3): 167-173.

Szkudelski, T. (2012). Streptozotocin-nicotinamide-induced diabetes in the rat. Characteristics of the experimental model. Journal Experimental Biology and Medicine 237: 481-490.

Taguchi, Y. (1985). Experimental Animals. Clea Japan, Inc. Tokyo.
World Health Organization (WHO). (1999). Definition of metabolic syndrome in definition, diagnosis and classification of diabetes melitus. World Helth Organization Departement of Noncommunicable Disease Suveillance. Geneva.

Yao, Y., Sang, W., Zhou, M. dan Ren, G. (2010). Antioxidant and r-glucosidase inhibitory activity of colored grains in china. Journal of Agricultural and Food Chemistry 58: $770-774$.

Yawadio, R.S., Tanimori, N. dan Morita. (2007). Identification of phenolic compounds isolated from red rices and their aldose reductase inhibitory activities. Food Chemistry 101: 1616-1625.

Zhang, G., Malik, V.S., Pan, A., Kumar, S., Holmes, M.D., Spiegelman, D., Lin, X. dan Hu, F.B. (2010). Substituting red rice for white rice to lower diabetes risk: A focus-group study in chineseadults. Journal of the American Dietetic Association 110: 1216-1221. 